\title{
Persistent Hypokalemic Paralysis in a Patient with Graves' Disease and Gitelman Syndrome
}

\section{Jin Woo Jeong and Tae Yang Yu}

Division of Endocrinology and Metabolism, Department of Medicine, Wonkwang University School of Medicine, Iksan, Korea

Thyrotoxic periodic paralysis (TPP) is a potentially life-threatening condition. Graves' disease accounts for the majority of cases of TPP. However, another diagnosis should be considered when repeated hypokalemic paralysis occurs in patients that maintain a euthyroid status. In this study, we report a case of persistent hypokalemic paralysis in a patient with Graves' disease and Gitelman syndrome and provide a brief review of Gitelman syndrome focused on challenges with diagnosis and management when it is accompanied by TPP.

Key Words: Hypokalemic periodic paralysis, Graves' disease, Gitelman syndrome

\section{Introduction}

Thyrotoxic periodic paralysis (TPP) is a potentially life-threatening condition, and the presentation often is misleading and leads to challenging diagnosis." Additionally, hypokalemic periodic paralysis can occur in patients without thyrotoxicosis. Previously, we reported two cases of hypokalemic periodic paralysis after low-dose glucocorticoid injection. ${ }^{2)}$

For most cases of TPP, Graves' disease also is present. Almost all patients completely recover from paralysis with potassium chloride supplementation and proper management. However, it is important to consider other diagnoses for cases with repeated hypokalemic paralysis that occur despite a euthyroid status.

We recently observed hypokalemic periodic paralysis in a patient with Graves' disease and a novel diagnosis of genetically confirmed Gitelman syndrome. In this article, we provide a brief review of Gitelman syndrome focused on the challenges of diagnosis and management when accompanied by TPP.

\section{Case Report}

A 42-year-old man was admitted to the emergency department with lower extremity paralysis that started three hours prior to his presentation. He did not have any significant past medical history. He was alert and oriented to person, place, and time. His vitals on presentation included a blood pressure of $120 / 80 \mathrm{mmHg}$, heart rate of 90 beats per minute, respiratory rate of 16 per minute, and temperature of $36.7^{\circ} \mathrm{C}$. Physical examination revealed lower extremity motor weakness of grades $2 / 5$ with no sensory deficit. The thyroid gland was palpable and slightly enlarged. The rest of the physical examination showed no abnormalities.

Laboratory tests revealed multiple abnormalities including hypokalemic metabolic alkalosis and thyrotoxicosis. Initial serum potassium level was 2.0 $\mathrm{mEq} / \mathrm{L}$ (reference range: $3.5-5.5$ ). Serum calcium and magnesium levels were $10.0 \mathrm{mg} / \mathrm{dL}$ (range: 8.4-10.2), and $1.5 \mathrm{mg} / \mathrm{dL}$ (range: $1.5-2.6$ ), respectively. Thyroid stimulating hormone (TSH) level was $<0.003 \mu \mathrm{lU} / \mathrm{mL}$

Received October 5, 2021 / Revised November 10, 2021 / Accepted November 17, 2021

Correspondence: Tae Yang Yu, MD, PhD, Division of Endocrinology and Metabolism, Department of Medicine, Wonkwang University Hospital, 895, Muwang-ro, Iksan 54538, Korea

Tel: 82-63-859-2670, Fax: 82-63-855-2025, E-mail: yutaeyang@gmail.com

Copyright (c) the Korean Thyroid Association. All rights reserved.

(1) (\$) This is an open-access article distributed under the terms of the Creative Commons Attribution Non-Commercial License (http://creative(c) (1) \& 8 commons.org/licenses/by-nc/4.0/), which permits unrestricted non-commercial use, distribution, and reproduction in any medium, provided the original work is properly cited. 
(range: $0.35-4.94$ ), free $\mathrm{T4}$ level was $1.99 \mathrm{ng} / \mathrm{dL}$ (range: $0.70-1.48$ ), and $\mathrm{T3}$ level was $299.65 \mathrm{ng} / \mathrm{dL}$ (range: 58-159). Anti-thyroperoxidase (TPO) antibody was $13.95 \mathrm{IU} / \mathrm{mL}$ (range: $0-34$ ). Anti TSH receptor antibody level was increased to $2.07 \mathrm{IU} / \mathrm{L}$ (range: $0-1.75$ ), and thyroid-stimulating antibody bioassay showed an increase to $156.6 \%$ (range: $0-140$ ). Table 1 provides an overview of the initial laboratory tests.

An EKG (electrocardiogram) was performed, and the results showed changes consistent with hypokalemia, including flattened $T$ waves and enlarged $U$ waves with a prolonged QT interval (Fig. 1). A chest $X$-ray and computed tomography of the head without contrast showed no acute abnormalities. The thyroid scan showed homogeneous and slightly increased uptake of technetium-99m pertechnetate in both lobes (Fig. 2; $3.2 \%$ radioactive thyroid uptake). Ultrasound results showed heterogeneous enlargement of the excess thyroid with increased vascularity. Based on the results of these tests, TPP was diagnosed in this patient with Graves' disease.

The potassium level increased to $4.1 \mathrm{mEq} / \mathrm{L}$ after intravenous and oral replacement, and motor abilities progressively recovered after maintaining normal po-

Table 1. Laboratory data, including basal hormone values

\begin{tabular}{lcc}
\multicolumn{1}{c}{ Test variables } & Result & Reference range \\
\hline Sodium $(\mathrm{mEq} / \mathrm{L})$ & 140 & $135-150$ \\
Potassium $(\mathrm{mEq} / \mathrm{L})$ & 2.0 & $3.5-5.5$ \\
Chloride $(\mathrm{mEq} / \mathrm{L})$ & 97 & $98-106$ \\
Calcium $(\mathrm{mg} / \mathrm{dL})$ & 10.0 & $8.4-10.2$ \\
Magnesium $(\mathrm{mg} / \mathrm{dL})$ & 1.5 & $1.5-2.6$ \\
Phosphorus $(\mathrm{mg} / \mathrm{dL})$ & 3.7 & $2.5-4.5$ \\
$\mathrm{pH}$ & 7.516 & $7.36-7.41$ \\
$\mathrm{pCO}(\mathrm{mmHg})$ & 39.0 & $35-48$ \\
$\mathrm{pO} 2(\mathrm{mmHg})$ & 81.4 & $83-108$ \\
$\mathrm{HCO}(\mathrm{m} \mathrm{M} / \mathrm{L})$ & 30.8 & $18-23$ \\
$\mathrm{O}_{2}$ saturation $(\%)$ & 96.3 & $95-98$ \\
TSH $(\mu / \mathrm{l} / \mathrm{mL})$ & $<0.003$ & $0.35-4.94$ \\
T3 $(\mathrm{ng} / \mathrm{dL})$ & 299.65 & $58-159$ \\
Free T4 $(\mathrm{ng} / \mathrm{dL})$ & 1.99 & $0.70-1.48$ \\
Plasma renin activity $(\mathrm{ng} / \mathrm{mL} / \mathrm{h})$ & 5.07 & $0.17-5.38$ \\
Aldosterone $(\mathrm{ng} / \mathrm{dL})$ & 17.36 & $3.0-16.0$ \\
Urine calcium $(\mathrm{mg} / \mathrm{dL}) / \mathrm{creatinine}(\mathrm{mg} / \mathrm{dL})$ & & (in supine position) \\
\hline
\end{tabular}

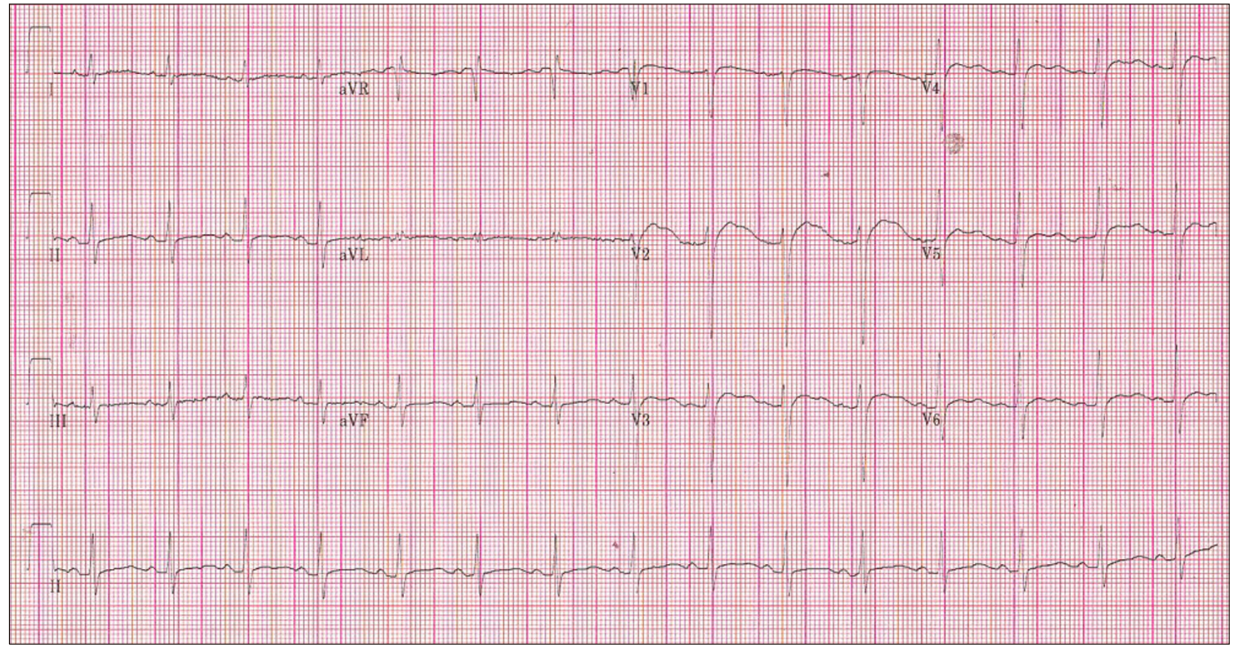

Fig. 1. EKG with changes indicative of hypokalemia. 


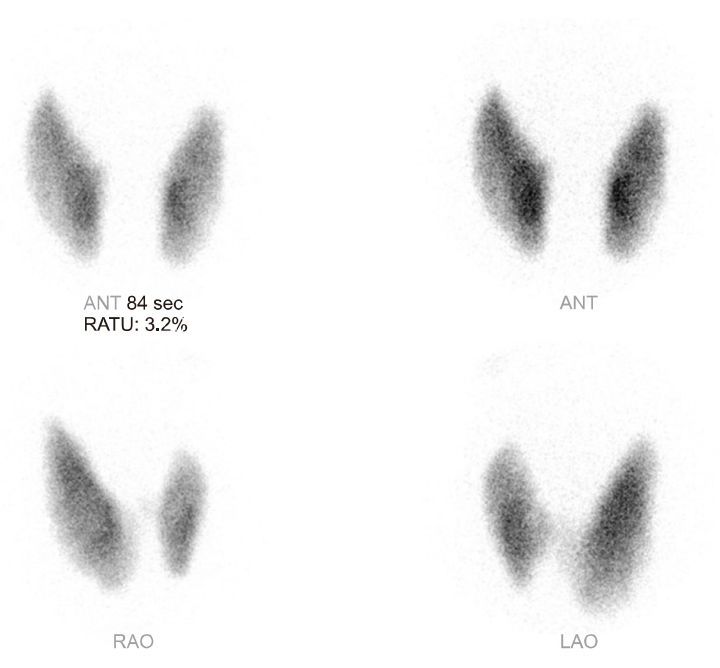

Fig. 2. Thyroid scan showing an enlarged thyroid gland and diffusely increased uptake of technetium-99m pertechnetate throughout both lobes $(3.2 \%$ radioactive thyroid uptake).

tassium level. The patient started taking $10 \mathrm{mg} /$ day of methimazole orally. On day 4, muscle power recovered completely, and he was discharged on $10 \mathrm{mg} /$ day of methimazole and oral potassium replacement. The dose of methimazole was reduced gradually to 5 $\mathrm{mg} /$ day.

However, on follow-up, the patient complained of repeated muscle weakness, even though a euthyroid state had been established after 1.5 months of methimazole. Laboratory assessment indicated that his potassium level had decreased to $2.1 \mathrm{mEq} / \mathrm{L}$. Because the severe hypokalemic condition persisted, the initial diagnosis was re-evaluated, and the possibility of coexistence of TPP and Gitelman syndrome was considered. We reviewed the initial laboratory tests and found hypokalemia, low normal limit of magnesium level, and hypocalcinuria with metabolic alkalosis. Gitelman syndrome was confirmed based on genetic analysis of the SLC12A3 gene. An SLC12A3 gene mutation was detected in the 1,868th nucleotide with a $\mathrm{T}$ to $\mathrm{C}$ mutation, which resulted in the change of leucine to proline.

The patient was given oral potassium and magnesium replacement with spironolactone. On follow-up, the patient's potassium level was maintained above $4.3 \mathrm{mEq} / \mathrm{L}$, and the serum magnesium level increased to $2.3 \mathrm{mEq} / \mathrm{L}$. No additional instances of paralysis have been repeated.

\section{Discussion}

In this study, we report persistent hypokalemic paralysis in a patient with the coexistence of Graves' disease and Gitelman syndrome. Previously, similar cases have been mostly reported in Asia, especially Japan ${ }^{3,4)}$ and China. ${ }^{5)}$ Most of them encountered the diagnostic challenges as our case. Compared with previous reports, our case showed lower potassium level $(2.0 \mathrm{mEq} / \mathrm{L})$ and less severe thyrotoxicosis. Therefore, early consideration of additional diseases might provide an accurate diagnosis without delay in our patient.

The exact mechanism of TPP is not understood. It is hypothesized that patients with TPP have an underlying channelopathy that is related to mutations in the KCNJ18 gene that encode Kir2.6, a skeletal muscle-specific Kir channel protein. ${ }^{6,7)}$ Under thyrotoxic conditions, the protein stimulates tissue responsiveness to beta-adrenergic signaling and increases sodium-potassium ATPase activity and drives potassium uptake into cells and results in hypokalemia. ${ }^{8)}$

Although any form of thyrotoxicosis can lead to TPP, Graves' disease is a leading cause. Treatment of TPP in Graves' disease is based primarily on potassium supplementation and regular doses of thionamide. Almost all patients completely recover from paralysis after proper management.

In comparison, Gitelman syndrome is an autosomal recessive, salt-loss tubulopathy that results from mutations in the SLC12A3 gene on chromosome 16q13, ${ }^{9,10}$ which encodes the thiazide-sensitive $\mathrm{NaCl}$ cotransporter. ${ }^{11)}$ This syndrome is characterized by hypokalemic metabolic alkalosis with hypomagnesemia and hypocalciuria caused by defective tubular reabsorption. ${ }^{12,13)}$ Hyperreninemic hyperaldosteronism that results from volume contraction without hypertension can be observed. ${ }^{14)}$ Clinical confirmation of suspected patients is based on molecular genetic testing, which should be performed in all patients. ${ }^{15)}$ The diagnosis can be confirmed based on the detection of biallelic inactivating SLC12A3 mutations. ${ }^{9,10)}$ 
The estimated prevalence of Gitelman syndrome is 1 in 40,000, with a possibility of a much higher prevalence in Asian populations. ${ }^{16,17)}$ Additionally, there is a wide spectrum of clinical manifestations from asymptomatic to severe forms. Some patients only experience mild symptoms such as tiredness, while others have seizures, tetany, muscle weakness, paresthesia, arrhythmias, and impaired quality of life. ${ }^{18)}$ Given that a substantial proportion of patients who are asymptomatic or have mild symptoms are not diagnosed, the actual prevalence of Gitelman syndrome might be underestimated.

According to an expert consensus statement, a liberal salt intake with oral magnesium and potassium supplements is a foundation for treating Gitelman syndrome. ${ }^{15)}$ The most critical challenge of treatment is the recurrence of hypokalemia. In a patient with recurrent and symptomatic hypokalemia, potassiumsparing diuretics (e.g., spironolactone, amiloride, eplerenone) that block the distal tubule sodium-potassium exchange are an add-on option. ${ }^{19,20)}$ In limited cases, the use of renin-angiotensin system blockers (angiotensin-converting-enzyme inhibitors and angiotensin receptor blockers) can be considered with caution. ${ }^{21)}$ Although urinary prostaglandin E2 level in Gitelman syndrome usually is normal, some cases have reported that prostaglandin synthase inhibitors (e.g., indomethacin) are effective in some patients. ${ }^{22,23)}$

The symptoms of Gitelman syndrome, including muscle weakness and electrolyte disorders such as severe hypokalaemia, are very similar to those of TPP in Graves' disease. Thus, clinicians should consider the coexistence of Gitelman syndrome in a patient with recurrent hypokalemic episodes in Graves' disease. Moreover, when evaluating cases of muscle weakness with hypokalemia, assessment of serum and urinary excretion of electrolytes and the acid-base status should be performed in addition to evaluation of thyroid function.

\section{Acknowledgments}

This study was supported by a grant from Wonkwang University in 2020.

\section{Conflicts of Interest}

No potential conflict of interest relevant to this article was reported.

\section{Orcid}

Jin Woo Jeong: https://orcid.org/0000-0003-0158-8144

Tae Yang Yu: https://orcid.org/0000-0003-0893-592X

\section{References}

1) Kung AW. Clinical review: Thyrotoxic periodic paralysis: a diagnostic challenge. J Clin Endocrinol Metab 2006;91(7):2490-5.

2) Ryu S, Yu TY, Kim HY, Cho CG. Low-dose glucocorticoid can lead to hypokalemic paralysis. Endocrine 2020;67(2):494-5.

3) Mizokami $T$, Hishinuma A, Kogai $T$, Hamada $K$, Maruta T, Higashi K, et al. Graves' disease and Gitelman syndrome. Clin Endocrinol (Oxf) 2016;84(1):149-50.

4) Oba T, Kobayashi S, Nakamura $Y$, Nagao M, Nozu K, Fukuda I, et al. A case of Gitelman syndrome that was difficult to distinguish from hypokalemic periodic paralysis caused by Graves' disease. J Nippon Med Sch 2019;86(5):301-6.

5) Zha B, Zheng P, Liu J, Huang X. Coexistence of Graves' disease in a 14-year-old young girl with Gitelman syndrome. Clin Endocrinol (Oxf) 2015;83(6):995-7.

6) Ryan DP, da Silva MR, Soong TW, Fontaine B, Donaldson MR, Kung AW, et al. Mutations in potassium channel Kir2.6 cause susceptibility to thyrotoxic hypokalemic periodic paralysis. Cell 2010;140(1):88-98.

7) Paninka RM, Carlos-Lima E, Lindsey SC, Kunii IS, Dias-da-Silva MR, Arcisio-Miranda M. Down-regulation of Kir2.6 channel by c-termini mutation D252N and its association with the susceptibility to thyrotoxic periodic paralysis. Neuroscience 2017;346:197-202.

8) Rhee EP, Scott JA, Dighe AS. Case records of the Massachusetts General Hospital. Case 4-2012. A 37-year-old man with muscle pain, weakness, and weight loss. N Engl J Med 2012;366(6): 553-60.

9) Mastroianni N, De Fusco M, Zollo M, Arrigo G, Zuffardi $\mathrm{O}$, Bettinelli A, et al. Molecular cloning, expression pattern, and chromosomal localization of the human $\mathrm{Na}-\mathrm{Cl}$ thiazide-sensitive cotransporter (SLC12A3). Genomics 1996;35(3):486-93.

10) Riveira-Munoz E, Chang Q, Bindels RJ, Devuyst O. Gitelman's syndrome: towards genotype-phenotype correlations? Pediatr Nephrol 2007;22(3):326-32.

11) Melander O, Orho-Melander M, Bengtsson K, Lindblad U, Rastam L, Groop L, et al. Genetic variants of thiazide-sensitive $\mathrm{NaCl}$-cotransporter in Gitelman's syndrome and primary hypertension. Hypertension 2000;36(3):389-94.

12) Gitelman HJ, Graham JB, Welt LG. A new familial disorder characterized by hypokalemia and hypomagnesemia. Trans Assoc 
The Coexistence of Graves' Disease and Gitelman Syndrome

Am Physicians 1966;79:221-35.

13) Simon DB, Nelson-Williams C, Bia MJ, Ellison D, Karet FE, Molina AM, et al. Gitelman's variant of Bartter's syndrome, inherited hypokalaemic alkalosis, is caused by mutations in the thiazide-sensitive Na-Cl cotransporter. Nat Genet 1996;12(1):2430.

14) Cruz DN, Simon DB, Nelson-Williams C, Farhi A, Finberg $\mathrm{K}$, Burleson L, et al. Mutations in the $\mathrm{Na}-\mathrm{Cl}$ cotransporter reduce blood pressure in humans. Hypertension 2001;37(6): 1458-64.

15) Blanchard A, Bockenhauer D, Bolignano D, Calo LA, Cosyns $\mathrm{E}$, Devuyst $\mathrm{O}$, et al. Gitelman syndrome: consensus and guidance from a kidney disease: improving global outcomes (KDIGO) controversies conference. Kidney Int 2017;91(1): 24-33.

16) Hsu YJ, Yang SS, Chu NF, Sytwu HK, Cheng CJ, Lin SH. Heterozygous mutations of the sodium chloride cotransporter in Chinese children: prevalence and association with blood pressure. Nephrol Dial Transplant 2009;24(4):1170-5.

17) Kondo A, Nagano $C$, Ishiko $S$, Omori $T$, Aoto $Y$, Rossanti $\mathrm{R}$, et al. Examination of the predicted prevalence of Gitelman syndrome by ethnicity based on genome databases. Sci Rep 2021;11(1):16099.
18) Cruz DN, Shaer AJ, Bia MJ, Lifton RP, Simon DB, Yale Gitelman's and Bartter's Syndrome Collaborative Study Group. Gitelman's syndrome revisited: an evaluation of symptoms and health-related quality of life. Kidney Int 2001;59(2):710-7.

19) Colussi G, Rombola G, De Ferrari ME, Macaluso M, Minetti L. Correction of hypokalemia with antialdosterone therapy in Gitelman's syndrome. Am J Nephrol 1994;14(2):127-35.

20) Ito $Y$, Yoshida M, Nakayama M, Tsutaya S, Ogawa K, Maeda $\mathrm{H}$, et al. Eplerenone improved hypokalemia in a patient with Gitelman's syndrome. Intern Med 2012;51(1):83-6.

21) Brambilla G, Perotti M, Perra S, Dell'Oro R, Grassi G, Pincelli AI. It is never too late for a genetic disease: a case of a 79-year-old man with persistent hypokalemia. J Nephrol 2013;26(3):594-8.

22) Larkins $\mathrm{N}$, Wallis $\mathrm{M}$, McGillivray $\mathrm{B}$, Mammen C. A severe phenotype of Gitelman syndrome with increased prostaglandin excretion and favorable response to indomethacin. Clin Kidney J 2014;7(3):306-10.

23) Blanchard A, Vargas-Poussou R, Vallet M, Caumont-Prim A, Allard J, Desport E, et al. Indomethacin, amiloride, or eplerenone for treating hypokalemia in Gitelman syndrome. J Am Soc Nephrol 2015;26(2):468-75. 